\title{
Developments
}

\section{Risk Regulation Approach to EU Policy against Terrorism in the light of the ECJ / CFI jurisprudence}

\author{
By Marta Simoncini*
}

\section{A. Introduction}

In order to get a better understanding of the current relationship between liberty and security in the European Union (EU), the essay adopts a new approach to counterterrorism matters, namely by availing itself of Administrative Law, and focuses on a specific case study, the European Community's (EC) regulations on freezing the assets of the terrorists as well as those of the people and entities associated with the terror network and blacklisting the identified subjects.

In demonstrating that the current model of security is based on the implementation of administrative powers, the analysis shows that the expansion of the notion of emergency has introduced a risk assessment perspective in the management of the counter-terrorism policies. From this standpoint, it is possible to argue that the real nature of such emergency powers consists of a reallocation of powers to the public administration, in the attempt to prevent new attacks from occurring. If this is the actual administrative model of organisation and action in counter-terrorism matters, in the absence of a stricto sensu emergency condition, the principles and the rules of Administrative Law must be restored, in order to limit the administration's discretion in the enforcement of similar powers and to ensure the protection of fundamental rights.

In particular, by building upon the trend of extensive case law, this essay searches for a European administrative model of security of rights, which could be paired with the constitutional and criminal rights of protection in the deployment of the administrative action. If we read counter-terrorism policy as an aspect of risk regulation, rather than an emergency situation, it is essential to realise how a proper balance between the collective interest of security and the respect for individual rights could be achieved at the administrative level.

From this perspective, the aim is to bring to light the EU's effective capability to protect rights in the implementation of security-related policies. In particular, the analysis is centred on the EU courts' case law on the legitimacy of such regulations, due to the

\footnotetext{
*Ph.D. in Administrative Law, University of Pisa. Email: marta81@sssup.it I would like to thank Federico Fabbrini and Nikolaos Lavranos for their valuable comments and remarks. Usual disclaimers apply.
} 
essential role played by the courts in balancing the protection of individual liberties with the collective interest of security, to such an extent that they appear as a demiurge of the effectiveness and coherence of the European model of protection of fundamental rights.

\section{B. The legal strategy against terrorism}

The struggle against international terrorism is based on multilevel policies, conducted in different ways to tackle the phenomenon and to prevent future attacks from occurring.

Looking through the lens of Administrative Law, said strategies are characterised by the gathering of public information, in order to contrast the actual or potential threat to the ordinary socio-political relations. In particular, Western democracies have enhanced the threshold of public control, aiming at using the collected information as a precious weapon to fight terrorism and, in the meantime, reassuring citizens of the State's capability of reacting to such indiscriminate violence ${ }^{1}$. More precisely, the anti-terrorism regulation introduces extraordinary powers, in order to protect citizens against terrorist attacks, allowing the administration to reassure them of the continuous capability of the State to bridge the gap in security, at the cost of increasing the administrative control over the citizens. However, the common man is more likely than the suspected offender to be affected by the correlation of the power to the information gathered ${ }^{2}$. As a result, the attempt to give the administration the capability, at first, to prosecute and, in the long run, to prevent the casualties generated by episodes of terrorist violence, generates a continuous request of new elements, above all personal data. It applies to the "Security" or "Prevention" State, as defined by Habermas, which is set up when the administrative action is not merely guided by the law, as it happens in the Liberal State, but is also supported by other resources, such as information and specialist knowledge ${ }^{3}$.

This strategy has involved the whole administrative action, namely both the law enforcement and the intelligence activities. In the former case, the administrative powers have been implemented in the exercise of traditional competences, forcing the fundamental principle of the rule of law, in the attempt to regulate the relations between

\footnotetext{
${ }^{1}$ See Bruce Ackerman, The emergency constitution, 113 YALE LAW JOURNAL 1029, 1031 (2004); Id., BEFORE THE NEXT AtTACK: Preserving Civil Liberties in AN Age of Terrorism 44 (2006).

2 See David Lyon, Surveillance After September 11 (2003), Italian translation: Massima sicurezZa. Sorveglianza E GUERRA AL TERRORISMO 170 (2005). In particular, the Author observes that the more power is connected to personal data, the more surveillance becomes a political matter.

${ }^{3}$ See Jurgen habermas, Between Facts and Norms. Contributions to a Discourse Theory of LaW and Democracy (1996), Italian translation: FATTI E NORME. CONTRIBUTI A UNA TEORIA DISCORSIVA DEL DIRITTO E DELLA DEMOCRAZIA 516 (1996).
} 
citizens and State; on the contrary, in the latter, the State's capability to gather useful information to protect the national security has been enhanced.

Actually, the elusion of the rule of law - favored by the introduction of data - sharing practices ${ }^{4}$ - reduces the capability itself of citizens to know how the administration intends to use the information gathered (and, in particular, use personal data).

Such an implementation of the public information resources determines, as a consequence, a sensible decrease in the citizens' capability to exercise their ordinary rights and new restrictions in the access to public services. However, even if justified from the need to ensure collective security, high transactional costs are involved, and this is particularly noteworthy when the protection of fundamental rights is at stake. The real problem is that the limitation of subjective rights - restricted by public rulings - in the attempt to implement a preventive protection system against terrorism thus guaranteeing public security, is functional to overcoming emergency situations, but it is likely to become an authentic Trojan horse if maintained much longer than the persistence of the crisis.

In such a context, the menace is double-headed: the terrorist threat could imply the risk of an abuse of administrative powers. As a matter of fact, the batch of data can turn into a boomerang, hitting the victims, rather than the offenders, and such distorted effect is amplified by the lack of transparency, which prevents the interested parties from defending themselves against the authority of the police to collect information. In this perspective, international terrorism constitutes a real legal challenge to the EU system, putting to test the principles of the integration process as well as the effectiveness of the European protection of fundamental freedoms, beyond the first pillar. Moreover, it highlights the weakness and the fragmentation of the European edifice in security matters.

\footnotetext{
${ }^{4}$ To this end, both those administrative sectors have developed practices of data-sharing, which allow each to strengthen the cognitive resources, cross-checking data gathered by the different agencies appointed for varied administrative functions. It seems a great contribution to the increase of the public information patrimony's potentiality, because this way the public administration's structural fragmentation has been overcome, enhancing the public capability to exert control and, as a consequence, national security. However, the mentioned datasharing practices hide inner risks, which stem from the difficulty of selecting and interpreting relevant data, and even of communicating them at the right moment, so as not to prejudice the prospective added value of confidentiality. Indeed, from a legal point of view, resorting to those practices, in the absence of an expressed legal provision or of an executive order, affects the protection of fundamental rights. In this perspective, see Hans De Bruijn, One fight, one team: the 9/11 Commission Report on intelligence, fragmentation and information, 84 Public AdMINISTRATION 267, 273-276 (2006). A clear example comes from the US Presidency Executive Order No. 13356, 69 Fed. Reg. 53599, 53600-01 (1 September 2004), aimed at favouring the exchange of terrorism-related information among executive agencies, which only later was received in the Intelligence Reform and Terrorism Prevention Act 2004, the statute attempting to put into practice the recommendations of the 9/11 Commission, charged with the task of examining the American national security problem after the attacks of 2001. See THE NATIONAL Commission on TeRroRist AtTACKS Upon the United States, Final RePORT 408 (2004). In particular, the Commission underlined the importance of carrying out "integrated, all-source analysis", in order to face the terrorist issue, stating that "without it, it is not possible to 'connect the dots"'. In this regard, see DANIEL J. SOLOVE, Marc Rotenberg, PAUl M. SCHWARTZ, Information Privacy LaW 317-318 (2001).
} 


\section{From the emergency legislation's approach to the risk regulation's model}

Whereas the counter-reaction to international terrorism has determined a further enhancement of public control, in the attempt to guarantee collective security, public regulation was not limited to a response to emergency situations, but aimed at preventing new attacks from occurring. The case of blacklists, which will be examined later in this essay, is a clear example of the States' need to fight terrorism at its root, facing the phenomenon as a political problem and not focusing exclusively on the containment of its effects and consequences. In this perspective, if the purpose of the regulation is valuable and necessary, the means through which that aim is carried out are inadequate inasmuch as they do not strike a proper balance between the protection of fundamental rights, which characterises the Western democracies, and the collective interest in security.

The real issue is related to the application of emergency legislations to no current emergency. As a matter of fact, such use ndorses the establishment of a kind of counterterrorist state, which carries out a paradoxical condition of "permanence of the temporary" ${ }^{\prime \prime}$ and favors an extensive interpretation of the concept of emergency. As a result, this notion includes not only the extraordinary and unforeseeable facts which justify the exceptional regulation, but alsothe probability of such events, which is to be referred to a different management system: $f$ the risk administration.

The consequence is that such a disguised emergency regime places in true danger the very foundation and the respect of the rule of law, core principle shaping the nature of Western democracies.

From this standpoint, although the anti-terrorism regulation grants the administration a high level of control over the citizens' socio-economic behaviors and a strong capacity to rule on their liberties, the presumed necessity of such an expansion in the administrative surveillance, when managed by the government secretly, collides in the long run with the hazard of abuse of those intrusive powers ${ }^{6}$.

More generally, the problem at stake is the exercise of extra-ordinary powers in conditions that are not, strictly speaking, classifiable as emergencies in the narrow sense, but which can be considered subject to risk, and enter the day-to-day dimension, more or less

\footnotetext{
${ }^{5}$ David Dyzenhaus, The Permanence of the Temporary: Can Emergency Powers Be Normalized?, in THE SECURITY OF FREEDOM: ESSAYS ON CANADA'S ANTI-TERRORISM BILL, 21 (R.J. Daniels, P. Macklem \& K. Roach eds., 2001).

${ }^{6}$ See Douglass Cassel, International Human Rights and the United States Response to 11 September, in LEGAL INSTRUMENTS IN THE FIGHT AGAINST INTERNATIONAL TERRORISM, 251, 293-295 (C. Fijnant, J. Wouters and F. Naert eds., 2004).
} 
intensely ${ }^{7}$. The institutionalisation of the sources of hazard allows the political sphere to broaden its own competence to intervene, making of the emergency state a permanent condition, creating "a tendency to a 'legitimate' totalitarianism of threat prevention" ${ }^{8}$.

From this perspective, the prevention of terrorism cannot be construed on the same assumptions of emergency without distorting the emergency presupposition and increasing the costs of the protection of rights and principles $^{9}$. This happens because the real mission of those derogating legislations, approved with a contrasting function, is the protection from the threat of terrorism, while ignoring or underestimating the hazard of keeping in force emergency norms that largely pursue the different function to regulate risks. To put it in a nutshell, the inner danger of such a misleading purpose is that rights tend to be overlooked in emergency cases and the different attitude toward the same problem bears its consequences in terms of judicial protection.

The acknowledgment of the permanence of the threat - that is radically at odds with the feature of any emergency - involves the need to redraft emergency legislations, first of all recognising their substantial nature of risk regulation and, as a consequence, basing them on the different assumptions of risk management. More precisely, the latter bases the administration of the risk at issue on a preliminary assessment of the kind, the probability, and the possible damages of such risk. This sort of regulation is currently implemented in terms of environmental and food safety issues, and also in economic matters; its application to counter-terrorism matters could appear quite new, but it has already constituted the substance and the main goal of the antiterrorism regulations.

From this perspective, the restriction on the free movement of capitals, one of the EC's founding freedoms, is emblematic. It consists of the enforcement of precautionary measures, aimed at freezing the assets of those people and entities (suspected to be) linked to the terror network, but not connected to the territory or the administration of a third country. These are also called smart sanctions, due to their ability to affect the interested parties individually, rather than whole countries and their governments. To this end, after being identified, the subjects are included in lists, drafted at different levels of government and according to the evidence of their association to terrorism. In particular, two different kinds of terrorist lists must be distinguished: those drawn up on the grounds

\footnotetext{
${ }^{7}$ This condition has been called "daily endemic emergency" by MarioPilade Chiti, II rischio sanitario e l'evoluzione dall'amministrazione dell'emergenza all'amministrazione precauzionale, in ANNUARIO 2005. IL DIRITTO AMMINISTRATIVO DELL'EMERGENZA, 141, 142 (Associazione italiana dei professori di diritto amministrativo ed., 2005).

${ }^{8}$ ULRICH BECK, RISK SOCIETY. TOWARDS A NEW MODERNITY (1992), Italian translation, LA SOCIETÀ DEL RISCHIO. VERSO UNA SECONDA MODERNITÀ 103, 105 (2000).

${ }^{9}$ See WolfGANG SOFSKY, RISCHIO E SICUREZZA 155-157 (2005). According to the Author, the prevention's policies put the future security before the risk of the loss in liberty.
} 
of the Member States' international obligations and those founded on autonomous decisions of the EU institutions.

Whereas freezing financial resources and funds could be an efficacious method of combating the phenomenon at the root, such an operation has to comply with some proper guarantees in the attempt to restrict fundamental rights lawfully. In this context, the case-law related to those EC regulations on listing represents paradigmatically the attempt to impede the financing of terrorism by freezing the suspect assets. At the same time, tackling the issue of the fairness of proceedings and the effectiveness of the judicial protection, the European courts, and the European Court of Justice (ECJ) in particular, have played a key role in the maintenance of the coherence of the EU system.

\section{International blacklisting and EU Courts}

\section{UN blacklists}

A full understanding of the case-law dealing with the lists drafted by the United Nations (UN) requires a preliminary reconstruction of the main characteristics of said instruments. In particular, it is essential to understand the sources of information and the process, leading to their drawing up.

Since 1999, the UN, being the foremost institution responsible for the maintenance of peace and security all over the world, has adopted some resolutions in order to freeze assets of people and entities linked to Osama bin Laden and the Taliban, which have been implemented seamlessly after the fall of the Taliban regime, in concurrence with the spreading of international terrorist attacks.

To this end, the UN Security Council set up a listing system ${ }^{10}$, relied upon a Sanctions Committee, instituted inside the Council itself ${ }^{11}$ and implemented by the same Committee in collaboration with the States. In time, the listing process has been improved in the attempt of surrounding the name-inserting procedure with more guarantees, but it remains an essentially diplomatic course of action. First of all, it is not clear whether the Sanctions Committee's assessment is preceded by a fact-finding carried out by the

\footnotetext{
${ }^{10}$ The system of lists has been introduced in the UN Resolution 1333/2000. For an account of the listing process, see Clemens A. Feinäugle, The UN Security Council Al-Qaeda and Taliban Sanctions Committee: Emerging Principles of International Institutional Law for the Protection of Individuals?, 9 GERMAN LAW JOURNAL 1513 (2008).

${ }^{11}$ The Sanctions Committee was created in the UN Resolution 1267/1999, para. 6. In literature, see Andrea Bianchi, Assessing the Effectiveness of the UN Security Council's Antiterrorist Measures: the Quest for Legitimacy and Cohesion, 17 European Journal of INTERNATIONAL LAW 881, 883, 900-902 (2007); JeREMy M. FARRALL, THE UNITED Nations SANCTIONS AND THE RULE OF LAW (2007).
} 
Committee itself, or whether it is based merely on the Applicant State's report ${ }^{12}$. Notwithstanding, the UN Resolution 1617/2005 contributes to overcome the vague character of the previous provisions about the feasibility of listing requests, instituting a monitoring team to support the activity of both the States and the Committee.

Likewise, the delisting procedure at national level is subordinated to a preliminary process, in which applications for cancellation from the list are subject to the state consent, which has to be taken into account by the Sanctions Committee when settling on the case. In particular, a bargaining process could take place between the State who proposed the insertion of the name in the list and the State of residence of the petitioner.

Unanimous agreement on the assessment of the application is essential: should this requirement not be met, the case will be passed on the Security Council, which in turn has to decide unanimously. However, the UN Resolution 1730/2006 has set up a Focal Point, invested with power to conduct a preliminary screening of the delisting applications ${ }^{13}$. In the end, an attempt to overcome the deliberative deficit in the Security Council stems from the UN Resolution 1822/2008, which has introduced the duty for the Sanctions Committee to act complying with a fair and clear procedure and has provided an obligation to communicate charges to the parties involved and to check delisting applications opportunely.

The highly diplomatic nature of such a procedure is evident. First of all, it means that the sources of information underlying the motions of the States are deeply rooted in intelligence activities. Furthermore, it shows an incontrovertible weakness of those legal instruments provided to oppose to being included in such lists ${ }^{14}$. From this point of view, the fair interpretation rendered by the Italian "Corte di Cassazione", on the probationary value conferred to the lists must be remarked: in the endeavour to prove a terrorist offence, they are not considered suitable to bind the free convincement of the judge,

\footnotetext{
${ }^{12}$ It is noteworthy that the UN Resolution 1526/2004 provides for the applicant State's obligation to make a statement on the case, in which the reasons of the request must be specified.

${ }^{13}$ On the Focal Point, see Daniel Halberstam and Eric Stein, The United Nations, the European Union, and the King of Sweden: Economic Sanctions and Individual Rights on a Plural World Order, 46 COMMON MARKET LAW REVIEW 13 (2009); JOHANNES REICH, Due Process and Sanctions Targeted Against Individuals Pursuant to Resolution 1267 (1999) with an added note on European Court of Justice, Judgment in Joined Cases C-402/05 P and C-415/05 P, Yassin Abdullah Kadi and Al Barakaat International Foundation v. Council and Commission, September 3, 2008, 33 YALE JOURNAL OF. INTERNATIONAL LAW, electronic copy available at http://papers.ssrn.com/sol3/papers.cfm?abstract id=1268163, 4-5 (2008).
}

${ }^{14}$ See HALBERSTAM and StEIN, (note 13), 16 
because the method of inclusion does not provide a sufficient certainty over the affiliation to terrorist networks ${ }^{15}$.

\section{The approach of EU courts to UN blacklists: finding a way to protect rights}

Given this legal framework, the EU's role in the implementation of that kind of instruments to struggle against terrorism has to be analysed, paying a specific attention to the case-law developed on the legitimacy of UN blacklists.

First of all, it should be noted that the EU puts into effect those international resolutions though two different actions in the EU's pillar-shaped legal framework: at first, by adopting common positions in the second pillar (Common Foreign and Security Policy - CFSP), it intended to implement peace policies at the European intergovernmental level, and then enact them through EC regulations aimed at giving a direct applicability to the UN discipline.

The realisation of the asset-freezing precautionary measures tests the EU system of protection of fundamental rights, targeting in particular the fairness of the administrative proceedings and the effectiveness of the subsequent jurisdictional protection. The core of the matter lies on the relations between national, EU and UN legal orders, because the EC regulations restrict their action to the fulfilment of UN blacklists.

More specifically, before a recognized prevalence of the UN legal order, laid down in the art. 103 UN Charter, States must comply with the Security Council's decisions ${ }^{16}$. Respecting the duty resting upon Member States, the EC Treaty does not affect their UN obligations, ruling that its provisions do not apply to previously stipulated treaties and to agreed measures for peace and security ${ }^{17}$. Nevertheless, the EU position in the joint of legal orders is problematic, because it is not clear the kind of relation between the EU and the UN systems, considering that the EU is not a member of the UN organisation. The application of a mathematic transitive clause, according to which the respect of UN Law imposes on EU in force of the loyalty of Member States to the UN legal order, is not deprived of not foregone corollaries.

\footnotetext{
${ }^{15}$ Italian Supreme Court of Cassazione, sez. I, criminal, 17 January 2007, n. 1072. On the probational relevance of freezing lists the Corte di Cassazione has already pronounced in the case sez. I, criminal, 30 September 2005, n. 35427.

${ }^{16}$ Art. 25 UN Charter. Furthermore, in accordance with art. 48 (2) of the UN Charter, those "decisions shall be carried out by the Members of the United Nations directly and through their action in appropriate international agencies of which they are members".

${ }^{17}$ See respectively art. 307 and art. 297 EC Treaty.
} 
In this perspective, the Kadi case is emblematic, since it shows two different interpretations of the same legal premises, rendered by the Court of First Instance (CFI) and by the European Court of Justice (ECJ) respectively, on the relation between EU and $\mathrm{UN}^{18}$. Whilst the lower court built on the EC Treaty a pure hierarchical subordination of the EU to the UN global order, the higher court raised a functional dependence, recognising the primacy of UN Law without jeopardising the European system of competence ${ }^{19}$. In other words, the Court of First Instance pleaded incompetent to control the legitimacy of EC regulations, because the latter were acts bound to the implementation of provisions settled by the UN, which the EU courts have no power to examine ${ }^{20}$. On the contrary, the ECJ overruled that decision, stating that the EC is founded on the respect of the rule of law and no Community act can shirk judicial control ${ }^{21}$. As a consequence, the implementation

\footnotetext{
${ }^{18}$ On this issue see Maria Tzanou, Case-note on Joined Cases C-402/05 P \&C-415/05 P Yassin Abdullah Kadi \& Al Barakaat International Foundation v. Council of the European Union \& Commission of the European Communities, 10 GeRman LAW JoURnAL 123, 137-148 (2009); for a further analysis of the Kadi case see Marise Cremona's speech, European Law and International Law after Kadi, given at the University of Bristol, 3 November 2008.

${ }^{19}$ In this perspective, the courts gave a different interpretation of the relationship between EC law and International law, the $\mathrm{CFI}$ adopting a monistic approach, which considers the former a part of the latter, and the ECJ opposing a dualistic vision, which holds the EC domestic law as a distinct legal sphere from the international dimension. See Gráinne de Burca, The European Court of justice and the International Legal Order after Kadi, JEAN MONNET WORKING PAPER, 01/09, 2, 28, 34, available at: www.JeanMonnetProgram.org,; Andrea Gattini, Joined Cases C-402/05 P \& 415/05 P, Yassin Abdullah Kadi and Al Barakaat International Foundation v. European Council, judgment of the Grand Chamber of 3 September 2008, nyr, 46 COMMON MARKET LAW REVIEW 213, 230-231 (2009); Stefan Griller, International Law, Human Rights and the European Community's Autonomous Legal Order: Notes on the European Court of Justice Decision in Kadi, 4 EUROPEAN CONSTITUTIONAL LAW REVIEW 528, 549-552 (2008);

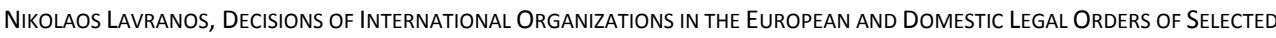
EU MEMBER STATES (2004). On the contrary, such clear-cut and general definition of the relation between legal orders is considered useless by Tzanou, who prefers to reserve "the ECJ's euro-centric approach" to the analysis of the protection of fundamental rights. See Tzanou (note 18), 147-148, 151. For a further frame on the relationship between European Law and International Law, see Bjørn Kunoy and Anthony Dawes, Plate Tectonics in Luxemburg: the Ménage à Trois between EC Law, International Law and the European Convention of Human Rights Following the UN Sanctions Cases, 46 COMMON MARKET LAW REVIEW 73, 83-100 (2009).

${ }^{20}$ In particular, the CFI founded such subordination to the UN obligations referring (paras. 192-200) to the analogy with the Joined Cases C 21-24/72, International Fruit Company, [1972] ECR 1219, where the ECJ held that the GATT agreement was binding on the EEC. However, EC is not a member of the UN and this circumstance alters the same validity of the functional succession's paradigm. In this regard, see Mehrdad Payandeh and Heiko Sauer, European Union: UN sanctions and EU fundamental rights, 7 INTERNATIONAL JOURNAL OF CONSTITUTIONAL LAW 306, 311 (2009); HALBERSTAM and STEIN (note 13), 45-46. On those premises the CFI decided in Case T-306/01, Ahmed Ali Yusuf e Al Barakaat International Foundation v. Council of European Union and European Commission, [2005] ECR II-3533, and Case T-315/01, Yassin Abdullah Kadi v. Council of European Union and European Commission, [2005] ECR II-3649. The same conclusions were worked out in the CFI, Joint Cases T- 253/02 and 49/04, Chafiq Ayadi, Hassan v. Council of European Union, [2006] ECR II-2139, [2006] ECR II-52, Summ. pub. See Joni Heliskoski, Case T253/02, Chafiq Ayadi v. Council, judgment of the Court of First Instance of 12 July 2006; Case T-49/04, Faraj Hassan v. Council and Commission, judgment of the Court of First Instance of 12 July 2006, nyr, 44 CoMmON MARKET LAW REVIEW 1143 (2007).

${ }^{21}$ See ECJ, Case 294/83, Les Verts v Parliament [1986] ECR 1339, para. 23. It is worth noting that this milestone of the EC case-law was highlighted by Eeckout, in order to move a "critique from the perspective of Community law"
} 
of UN provisions cannot imply a jurisdictional immunity of some acts, even if the courts cannot extend their control to the legitimacy of the UN decisions.

These different interpretations of the EU position in the global order have involved antithetic attitudes of the courts on the core of the problem of which level of protections of rights can be guaranteed by European courts with regard to counter-terrorism matters.

Following the hierarchical principle and reflecting a realistic, rather than a legalistic, approach to the pursuit of public interests ${ }^{22}$, the CFI declared itself unable to assure any effective judicial control, and it deferred to the competence to other actors. In particular, it found that in the absence of a specific EU power, the guarantees of fair proceeding and, above all, the right to be heard would be decided on at the Security Council level; moreover, the respect of the fundamental EC principle of an effective judicial protection would be ensured at the national level, where the refuse of the competent authorities to submit delisting requests to the UN Security Council Sanction Committee would be a reason to resort to national courts. On one hand, such a model of protection seems to presume a global equivalence of national legal systems ${ }^{23}$; on the other hand, it is worth noting that following the same reasoning the Court could have come to the conclusion of the necessity to respect the international human rights law laid down in the European Convention on Human Rights (ECHR), which is binds each EC Member State, but not for the Community as a whole ${ }^{24}$. The only competence that rested upon the EC court is an incidental control on the conformity of UN Law to the universal standards of protection of rights settled in the jus cogens ${ }^{25}$. This means a de facto suspension of the efficacy of the

to the CFI's judgment in the Kadi case. See Piet Eeckout, Community Terrorism Listings, Fundamental Rights, and UN Security Council Resolutions. In Search of the Right Fit, 3 EUROPEAN CONSTITUtIONAL LAW REVIEW 183, 198 (2007).

${ }^{22}$ Mustafa T. Karayigit, The Yusuf and Kadi Judgments: The Scope of EC Competences in Respect of Restrictive Measures, 33 LEGAL ISSUES OF ECONOMIC INTEGRATION 379, 397 (2006); Takis Tridimas and Jose A. Gutierrez-Fons, EU law, international law and economic sanctions against terrorism: the judiciary in distress, 32 FORDHAM International LaW Journal 660, 681 (2009); Pasquale De Sena and Maria Chiara Vitucci, The European Courts and the Security Council: Between Déboublement Fonctionnel and Balancing of Values, 20 EUROPEAN JOURNAL OF INTERNATIONAL LAW 193, 201-202, 210 (2009).

\footnotetext{
${ }^{23}$ See Maria Eugenia Bartoloni, Frammentazione di competenze e tutela giurisdizionale, in SICUREZZA COLLETTIVA E DIRITTI FONDAMENTALI IN TEMPO DI TERRORISMO 31, 47-48 (S. Lorenzon, G. Vaccari and V. Zanetti eds, 2008).

${ }^{24}$ In this sense see Christina Eckes, Judicial Review of European Anti-Terrorism Measures - The Yusuf and Kadi Judgments of the Court of First Instance, 14 EUROPEAN LAW JOURNAL 74, $89-90$ (2008). More precisely, the Author considers that if EU law is classified as international law, the UN resolution at stake ought to be in compliance with EU Law, and so with the ECHR and the general principles of EC Law; on the contrary, if EU law is domestic law, the international law shall prevail, but in so doing the Court has to apply not only the UN Law, but also the international human rights law, including the ECHR. For a further critique to the denial of protection of the fundamental human rights, see PIET EeCKOUt, Does EUROPE'S Constitution Stop AT THE WATER'S EDGE? LAW AND Policy in the EU's External Relations, Fifth Walter VAN Gerven Lecture (2005); see also EecKout (note 21), 190-198.

${ }^{25} \mathrm{CFI}$, Case T-306/01, Ahmed Ali Yusuf, paras. 277, 281 and 282. In the literature see Edoardo Chiti, La prevalenza del diritto delle Nazioni Unite su quello europeo, GIORNALE DI DIRITTO AMMINISTRATIVO 147, 151 (2006). See TRIDIMAS
} 
principle of laying claim, introducing an evident dichotomy with the standards of protection generally granted at the $\mathrm{EC} \mathrm{level}^{26}$ and moving the stage of defence from the judiciary to the diplomacy. As a result, the judgment attests the EC difficulty (if not its ineffectiveness) in assuring the respect of a fair proceeding and an effective jurisdictional protection, remedy that seems barely suited to the EC legal order's substantial characteristics $^{27}$.

Conversely, moving from the recognition that the prevalence of UN Law does not imply derogation of the primary EC Law ${ }^{28}$, the ECJ reaffirms its own power to control EC acts, restoring the respect of general principles and the protection of fundamental rights in the process of effectuation of a higher, and hence unquestionable, law ${ }^{29}$. Bringing back the effectiveness of the rule of law, the court does not introduce an indirect check over the legitimacy of UN provisions, but implies that no provision, in spite of its provenience, can alter the autonomy of the European legal order, introducing a counter-limit to the entry of rules conflicting with the standards of protection of rights recognised by the system itself ${ }^{30}$.

and GUTIERREZ-Fons (note 22), 681 who consider that "the CFI sought to reach a golden balance" between the primacy of UN Charter and the subjection of the Security Council "to principles endogenous to the legal system at the apex of which it stands", but such approach "is neither logically inevitable nor constitutionally secure".

${ }^{26}$ On the guarantees to an effective judicial protection see ECJ, Case 222/84, Johnston, [1986] ECR 1651; ECJ, Case C-97/91, Oleificio Borelli v Commission, [1992] ECR I-6313; EC], Case C-1/99, Kofisa Italia, [2001] ECR I-207; ECJ, Case C-424/99, Commission v Austria, [2001] ECR I-9285; ECJ, Case C-50/00 P, Unión de Pequeños Agricultores v Council, [2002] ECR I-6677.

${ }^{27}$ See Christian Tomuschat, Case T-301/01, Ahmed Ali Yusuf and Al Barakaat International Foundation v. Council and Commission, judgment of the Court of First Instance of 21 September 2005; Case T-315/01, Yassin Abdullah Kadi v. Council and Commission, judgment of the Court of First Instance of 21 September 2005, nyr, 43 COMMON MARKet LaW ReVIeW 537, 549 (2006). See also EeCKOUt (note 21), 198-206.

${ }^{28}$ In the Case C-459/03, MOX plant, [2006] ECR I-4635, the ECJ has already ruled that no international treaty can affect the autonomy of the EC legal order and the jurisdiction of the EC court over it. For an analysis of the case see N. Lavranos, The scope of the exclusive jurisdiction of the Court of Justice, 32EUROPEAN LAW REVIEW 83 (2007); Paul J. Cardwell and Duncan French, Who decides? The ECJ's Judgment on Jurisdiction in the MOX Plant Dispute, 19 JouRnal of EnVIRONMENTAL LAW 121 (2007); Federico Casolari, La sentenza MOX: Ia Corte di giustizia delle Comunità europee torna ad occuparsi dei rapporti tra ordinamento comunitario ed ordinamento internazionale, 12 IL DIRITTO DELL'UNIONE EUROPEA 327 (2007).

${ }^{29}$ Quoting Peter J. Spiro, Treaties, International Law, and Constitutional Rights, 55 STANFORD LAW REVIEW 1999, 2002 (2000), see TRIDIMAS and GUTIERREZ-Fons (note 25), 701, who underline "the constitutional hegemony of the EU" wrapped in the pronouncement of the ECJ (684) and consider the judgment "Euro-centric rather than internationalist".

${ }^{30}$ In particular, the Court's prohibition to derogate to the clause of protection of rights, settled in art. 6 EU Treaty, stems from the lack of any opposite indication in artt. 297 and 307 EC Treaty. Moreover, it finds the counter-limit premise in art. 300 (6) EC Treaty, according to which every new agreement requires favourable opinion of the same court, as it concerns the compatibility with the Treaty. See ECJ, Joint cases C-402/05 P e C-415/05 P, Yassin Abdullah Kadi and Al Barakaat International Foundation v. European Council, [2008] nyr, www.curia.eu.int, paras. 301-306. About the behaviour of the ECJ as a "domestic court", see HALBERSTAM and STEIN (note 13), 47, 68. 
This way the Court sets the distinction between international agreements and the EC Treaty, raising the latter to the constitutional charter of the Community legal order ${ }^{31}$.

In this perspective, the court reaffirms its own power to control the guarantees of fair proceeding in the listing process assured by the European Institution, allowing the parts subjected to restrictive orders to exercise their right to defence, first of all in the administrative stage and then in the judicial one, and also enabling the judges to verify the legitimacy of the measures adopted by EU institutions.

Notwithstanding, the court acknowledges the security objective, pursued with the introduction of precautionary measures, and takes into account the collective interests in that matter, tempering to this end the guarantees of due process of law with the reasons of the adopted orders' effectiveness ${ }^{32}$.

As a consequence, even though both the judges move from the acceptance of a functional restraint to the individual property right in order to satisfy some interests of general relevance, the granted protection is very different in the two judgments: whilst the Court of First Instance (CFI) does not identify in the precautionary restrictions a breach to jus cogens, the Court of Justice (ECJ) holds the same limitation to be unjustified for not being founded on a proper due process of law and resulting in the court nor being able to control the legitimacy (or the proportionality) of the measure.

More specifically, the CFI excluded the inhuman and degrading nature of the UN measures on the basis of the fact that the contested regulations do admit some derogation, in order to fulfil the fundamental needs of people ${ }^{33}$. In this perspective, the Court deemed contrary

\footnotetext{
${ }^{31}$ In this perspective, it is worth mentioning the sharp analysis of M.T. Karayigit, who criticised the CFI judgment in the Yusuf and Kadi cases, because it fails to acknowledge the difference between the international and the Community legal order, "which is far from being as sub-system of or subordination to international law through the constitutionalisation process", anticipating the core of the ECJ pronouncement on appeal. See KARAYIGIT (note 22), 395. Furthermore, on the development of a counter-limit doctrine at EC level see Aldo Sandulli, La Corte di giustizia europea ed il dialogo competitivo tra le corti, in IL DIRITTO AMMINISTRATIVO OLTRE I CONFINI 189, 197-200 (S. Battini et al. eds., 2008); Edoardo Chiti, I diritti di difesa e di proprietà nell'ordinamento europeo, GIORNALE DI DIRITTO AMMINISTRATIVO 1093, 1094-1095 (2008). More specifically, the Author finds in the position of the Court not only the result of the UN Law's translation on a regional scale, but also a source of a further development of global law.

${ }^{32}$ See ECJ, Joint cases C-402/05 P e C-415/05 P, Yassin Abdullah Kadi and Al Barakaat International Foundation v. European Council, para. 344. Before the annulment of the CFI judgment for error in law and of the Council Regulation (EC) No 881/2002, as far as it concerns Mr Kadi and the Al Barakaat International Foundation, the effects of the contested regulation are, by virtue of art. $231 \mathrm{EC}$ Treaty, maintained for a brief period that may not exceed three months, in order to allow the Council to repair to the tort without prejudicing the effectiveness of the restrictive measures imposed by the regulation in a serious and irreversible manner (see paras. 373-376). See Tzanou (note 18), 152, 153.

${ }^{33}$ In accordance with art. 1 Reg. 561/2003, art. 2a is added to the contested regulation and it provides, at (1), that "art. 2 shall not apply to funds or economic resources where: (a) any of the competent authorities of the
} 
to jus cogens only arbitrary deprivations of the property right ${ }^{34}$, although the fundamental public interest safeguarded through the fight against international terrorism and through the legitimate UN action does not affect the very substance of the right ${ }^{35}$.

On the other side, the ECJ develops the right to property in the light of both the general principles of Community Law and the First Additional Protocol to the $\mathrm{ECHR}^{36}$. In this perspective, the Court is going to evaluate the proportionality of such measures, but if in principle the contested regulation imposes restrictions, which might be justified, in the circumstances of the case the evaluation is prevented by the absence of any reasonable guarantee of opposing to the decision for the plaintiffs ${ }^{37}$.

\section{E. EU blacklisting and EU courts}

\section{EU blacklists}

Aside from the implementation of UN lists, the European Union has also developed an autonomous system of precautionary listing of people and entities suspected to be associated with terror networks, focusing on different kinds of terrorism. In particular, the EU blacklists deals not only with the international feature of the phenomenon, but also with the local, intra-community, violence, founded on nationally focused strategies and claims. This distinction is functionally connected with the kind of counter-action to be

\footnotetext{
Member States, as listed in Annex II, has determined, upon a request made by an interested natural or legal person, that these funds or economic resources are: (i) necessary to cover basic expenses, including payments for foodstuffs, rent or mortgage, medicines and medical treatment, taxes, insurance premiums, and public utility charges; (ii) intended exclusively for payment of reasonable professional fees and reimbursement of incurred expenses associated with the provision of legal services; (iii) intended exclusively for payment of fees or service charges for the routine holding or maintenance of frozen funds or frozen economic resources; (iv) necessary for extraordinary expenses; and (b) such determination has been notified to the Sanctions Committee; and (c) (i) in the case of a determination under point (a)(i), (ii) or (iii), the Sanctions Committee has not objected to the determination within 48 hours of notification; or (ii) in the case of a determination under point (a)(iv), the Sanctions Committee has approved the determination"; see CFI, Case T-306/01, Yassin Abdullah Kadi v.Council of European Union, paras. 288-291.

${ }^{34}$ See TRIDIMAS and GUTIERREZ-FONS (note 22), 31, who highlight that in the CFI's reasoning the function of jus cogens is "to lower substantially the degree of judicial scrutiny", comprising all the rights pleaded by the applicants, but allowing only a control on the arbitrariness of their restraint. Therefore, whether a review in point of jus cogens intervened, it would amount to a declaration of ultra vires action of the Security Council, which would break the presumptive immunity of UN Law. In this regard, see Eckes (note 24), 88. On the notion of jus cogens adopted by the CFI, see also HALBERSTAM and STEIN (note 13), 51-55; De BURCA (note 19), 26; GRILLER (note 19), 543-549.

${ }^{35}$ See CFI Case T-306/01, para. 248.

${ }^{36}$ See ECJ Joined Cases C-402/05 P e C-415/05 P, paras. 355-356.

${ }^{37}$ See $I d .$, paras. $366-370$.
} 
taken. The listing aims to freeze assets associated with international terrorism while it also functions to stimulate judicial and police cooperation against those phenomena of intracommunity significance ${ }^{38}$.

Compared with the UN procedure of listing, the inclusion on EU lists is founded on a more reliable legal basis, because the request can be carried out only if a criminal proceeding was initiated or the criminal action for the offence of terrorism was exercised by a judicial authority, or by an equivalent one; moreover, a six-month revision of the list allows the verification on the suitability of the names enclosed ${ }^{39}$. It is evident that the connection with the criminal charge provides the precautionary tool with a different legal value, although the initiation of the preliminary inquiry is susceptible of different interpretations. Notwithstanding, the absence of a hearing in the listing stage and obstacles to the cancellation from the list bring about some complaints on the use of such instruments to fight terrorism. More specifically, the EC listing process is based on warning submissions by Member States, which are not necessarily endorsed by the jurisdictional authorities. At the same time, there are no EU guidelines on the drafting method and no organism has been set up within the Council to controls the process. As a consequence, the drawing up stage sees no specific role played by the EU institutions with respect to fair proceeding.

\section{Ruling on EU blacklists}

In this context, it is important to recognise the fundamental role played by the system of courts in the protection of individual rights. Resuming their own competence to rule on the legitimacy of those lists, the courts have based it upon the control of the correct use of discretion, by European institutions, in the exercise of their Community competences. In keeping with the European framework, the courts have restored the guarantees of effectiveness in the administrative process and in the judicial review, moving from a set of powers conferred by the Treaties and not from a binding competence of international derivation $^{40}$. In this regard, it is particularly meaningful the OMPI saga, namely the

\footnotetext{
${ }^{38}$ European Council Common Positions 27 December 2001, 2001/930/CFSP, on combating of terrorism, 2001/931/CFSP, on the application of specific measures to combat terrorism. In particular, the distinction between the insertion in the list with an assets-freezing purpose and that finalised to the police and judicial cooperation is specified in the Annex to the Common Position 2001/931/CFSP.

${ }^{39}$ Art. 1, (4) and (6), 2001/931/CFSP.

${ }^{40}$ See CFI Case T-228/02, Organisation des Modjahedines du peuple d'Iran v. Council of European Union, [2006] ECR II-4665, where the right to a fair hearing has been reaffirmed "since the identification of the persons, groups and entities contemplated in Security Council Resolution 1373 (2001), and the adoption of the ensuing measure of freezing funds, involve the exercise of the Community's own powers, entailing a discretionary appreciation by the Community" (para. 107) and "the Community does not act under powers circumscribed by the will of the Union or that of its Member States" (para. 106). It happens on the assumption that, "although Security Council Resolution 1373 (2001) provides inter alia in Paragraph 1(c) that all States must freeze without delay funds and other financial assets or economic resources of persons who commit, or attempt to commit, terrorist acts or
} 
judgments of the CFI on the legitimacy of the inclusion of the People's Mojahedin Organization of Iran (OMPI) in the funds-freezing list. In those cases the Court developed the statements laid down in the first pronouncement, focusing on the control over the correct exercise of discretionary power by the Council ${ }^{41}$.

More specifically, the respect of procedural guarantees becomes the key element to verify the legitimacy of such discretion, so that the procedure determines the definition of what is lawful. In this perspective, substantial errors turn into errors of procedure.

In particular, the correct use of the discretionary power implies, first of all, that in the factfinding stage of the proceeding all the relevant information are taken into account, in order to assess the situation and substantiate the conclusions; and, moreover, it entails that the final decision is consistent (namely its content complies with the presuppositions of the exercise of the discretionary power), and coherent with the legal order and the general principles. Finally, the duty to give reasons or, more generally the duty to disclose, plays a central role, because it compels the administration to show the evidence of its decisions and, as a consequence, allows the affected parties to organise their defence and the judge to control the adequacy of public measures ${ }^{42}$.

participate in or facilitate the commission of terrorist acts, of entities owned or controlled directly or indirectly by such persons, and of persons and entities acting on behalf of, or at the direction of, such persons and entities, it does not specify individually the persons, groups and entities who are to be the subjects of those measures. Nor did the Security Council establish specific legal rules concerning the procedure for freezing funds, or the safeguards or judicial remedies ensuring that the persons or entities affected by such a procedure would have a genuine opportunity to challenge the measures adopted by the States in respect of them" (para. 101). Later, the CFI carried through the same reasoning in Case T-47/03, Jose Maria Sison v. Council of European Union, [2007] ECR II-2047, paras. 139-154; Case T-327/03, Stichting Al-Aqsa v. Council of European Union, [2007] ECR II-79*, Summ.pub., paras. 53-65. For a detailed analysis of those cases, see N. Lavranos, Case-note: T-228/02 (Organisation des Modjahedines du peuple d'Iran), 8 EUROPEAN HUMAN RIGHTS CASES 269 (2007); Id., Case-note: T47/03 and T-327/03 (Sison) and (Al-Aqsa), 8 EUROPEAN HUMAN RIGHTS CASES 991 (2007).

${ }^{41}$ CFI Case T-256/07, People's Mojahedin Organization of Iran v. Council of European Union, [2008] nyr, www.curia.eu.int, paras. 130-139; CFI Case T-284/08, People's Mojahedin Organization of Iran v. Council of European Union, [2008] nyr, www.curia.eu.int, paras. 54-55. The last word on this saga is for the ECJ, which is about to pronounce on the pending case C-576/08.

${ }^{42}$ The latest judgment which stated the necessity to provide adequate reasons for the inclusion in the EU freezing list is Case T-229/02, PKK v. Council of European Union, [2008], where the CFI did not uphold a disclosure after the instauration of the judicial proceeding, in order to make up for the previous failure to state reasons, being at that time the rights of the defence already prejudiced (see para. 68). However, TRIDIMAS and GUTIERREZ-Fons (note 22), 57, highlight that the court seems to separate "the right to receive evidence from the right of access to documents", distinguishing between the duty to disclosure and the principle of transparency, as the Case T110/03, 150/03, 405/03, Jose Maria Sison v. Council of European Union [2005], upheld by the ECJ in the Case C266/05 P [2007], demonstrates. In fact, the courts denied the applicant the right to know, in order to protect the confidentiality of the contested documents, without exempting the Council "from notifying the evidence" against him. 
In this perspective, at first the CFI stated that the Council had to take into account the pronouncement of the UK judicial authority competent to review the lawfulness of the Home Secretary's acts, the Proscribed Organisation Appeal Commission (POAC), allowing the appeal against the decision of proscription of OMPI, and ordering the Home Secretary to lay before the Parliament the draft of a new order removing the applicant from the blacklist ${ }^{43}$. On the contrary, the Council did not appear to comply, presenting instead an insufficient statement on the reasons of the inclusion in the EU list, which was completely inadequate to provide a legal justification for continuing to freeze the applicant's funds ${ }^{44}$. Similarly, in the next judgment on the case, the same court found that the Council breached the applicant's right of defence, having failed again to provide suitable reasons for the lasting inclusion of OMPI in the EU list, despite the cancellation of the organisation from the UK blacklist, after that the POAC's findings had been upheld by the Court of Appeal $^{45}$. In particular, basing its conclusion on the new information gathered from a judicial inquiry opened in France in 2001 and the supplementary charges brought in 2007 against alleged members of OMPI, the Council did not clarified how they could be considered a decision by a competent authority, according to art. 1 (4) of the Common Position 2001/931/CFSP ${ }^{46}$. Moreover, at the request of French authorities, the Council refused to communicate to the CFI the confidential documents, on which its decision was basically founded, preventing the Court from reviewing the lawfulness of the contested decision ${ }^{47}$.

Whereas the capability to protect fundamental rights against any unlawful use of powers conferred by the Treaties proved to have been recovered by the CFI, said competence was implemented by the ECJ, which prevented that the EU's formal architecture from turning into a substantial limit to the guarantee of the effectiveness of rights. In this respect, the ECJ's activism is particularly palpable in Gestoras pro Aministia and Segi cases, where the challenge posed to the protection of fundamental rights by the counter-terrorism policies risked collapsing with the EU's pillar construction. In the mentioned cases, the ECJ performed an operation of substantial interpretation of the rights involved, extending its jurisdiction over the formal assessment of the provisions, in order to grant the plaintiffs an effective level of protection.

More specifically, the EC judge recognised the necessity of granting effective protection also in the areas of II and III pillars, extending its jurisdiction to those abnormal common

${ }^{43}$ CFI Case T-256/07, para. 170.

${ }^{44}$ Id., paras. $176-185$.

${ }^{45}$ CFI Case T-284/08, paras. 40-41.

${ }^{46} I d$., paras. 56-57.

${ }^{47}$ Id., paras. 71-77. 
positions capable of producing legal effects in relation to third parties, derogating to art. 35 EU Treaty $^{48}$. In a broad interpretation of the competence provision, the Court demonstrates to be a factual, and not only a formal, guardian of the Treaties, competent to go beyond the strict limits of the pillars should a different approach be required by this case, with particular care for the complexity of the whole legal system. This is the reason why the right of listed parties to resort to EC courts and the capability of national judges to issue preliminary ruling on the same matters was recognised by the Court. However, in this context, it is noteworthy that the ECJ denied any faculty of the plaintiffs to claim for damages, although the Council of European Union stated the right to reparation of torts in art. 1 (6) of the Common Position 2001/931/CFSP and reaffirmed it on the $8^{\text {th }}$ recital of Council Decision 2003/48/JHA. This deceptive restriction of a legitimate right is the result of the adherence of the court's rulings to the order established by the Treaties: in the lack of any EC provision on the applicability of art. 288 EC Treaty, which regulates the liability of Community institutions, but in the first pillar area, the acknowledgement of a right to reparation of tort in the secondary sources of law is exorbitant from the Treaty legal system and, as a result, it is unable to constitute a suitable remedy, given the incapability of derived law to amend the primary legislation ${ }^{49}$.

Moreover, it must be noted that the admission of the legitimacy control on EU lists does not imply an unconditioned admissibility of the rights to defence, the need to strike a balance between liberty rights and security remaining indispensable. In this perspective, the key issue is finding a proper equilibrium between the individual interest in participating in the administrative proceeding and the transparency of the administrative action on one hand and the Administration's interest in secrecy, which guarantees the effectiveness of these measures, on the other hand.

The core of the individual rights toward the Administration is summed up in the right to a sound administration, laid down in art. 41 of the Charter of Fundamental Rights ${ }^{50}$, which gathers the minimum requirement to guarantee protection or, under a more confident point of view, a kind of foreseeable EU administrative fair proceeding at its embryonic

\footnotetext{
${ }^{48}$ ECJ Case C-354/04 P, Gestoras Pro Amnistía v. Council of European Union, [2007] ECR I-1579, paras. 52-54, and ECJ Case C-355/04 P, Segi Araitz Zubimendi Izaga and Aritza Galarraga v. Council of European Union, [2007] ECR I1657, paras. 53-54.

${ }^{49}$ See ECJ Case C-354/04 P, Id., para. 60; ECJ Case C-355/04 P, Id., para. 60.

${ }^{50}$ Art. 41, (1) and (2), disposed that "every person has the right to have his or her affairs handled impartially, fairly and within a reasonable time by the institutions and bodies of the Union. 2 . This right includes: a) the right of every person to be heard, before any individual measure which would affect him or her adversely is taken; $b$ ) the right of every person to have access to his or her file, while respecting the legitimate interests of confidentiality and of professional and business secrecy; c) the obligation of the administration to give reasons for its decisions." Even though the Charter is legally enforceable not yet, however it has been incorporated in the Treaty establishing a Constitution for Europe and, after the failure of that project, actually it is part of the Treaty of Lisbon.
} 
state. In particular, this norm provides for the European citizens' right to a fair hearing, the right to know and the administrative duty to give reasons for decisions. In this perspective, it is worth noting the Sison case, which shows the attention paid by EC courts to the mixture of such different instances. In fact, both the CFI and the ECJ on appeal denied the plaintiff the right to know the Council's documents which his insertion in EU lists was based on, decreeing the prevalence of the public interest of EC institutions to secrecy on the individual right to a fair procedure, in accordance with the exemption of laid down in art. 4 of Regulation $1049 / 2001^{51}$.

\section{F. Assessing the findings of the EU courts on blacklists}

The analysis of the European jurisprudence on listing measures confirms the central role played by the courts in the process of integration.

Both the $\mathrm{CFI}$ and the ECJ worked out a balance between the reasons of security and the guarantees of liberty, but there is no doubt that the reasoning of the court of appeal goes further ahead, pushing the integration forward. In fact, whilst the CFI has identified an insuperable limit in the effectiveness of the European legal order, the ECJ does not fear the Hercules columns, going beyond the apparent borders of its competence by setting up counter-limits. In other words, the degree of jurisdictional deference varies between the two courts: before the recognition of incompetence to control the legitimacy of UN resolutions, the CFI gives up the protection of fundamental EC rights, while the ECJ claims its living competence to rule on the EU institutions' respect of rights and general principles $^{52}$. This way, the dichotomy "bound vs. discretionary competence" of the EU Institutions fades away in their general duty to respect the principle of fairness in the implementation of every policy, which is able to prejudice subjective position of right. This way the Court of justice tries to avoid the fragmentation of institutional competences, which would involve a breaking of the judicial protection. It emerges in the field of international obligation not only through the introduction of the mentioned counter-limit reasoning, but also within the reconstruction of the normative foundation of the contested regulation. In this last case, the ECJ finds a connection between artt. 60 and $301 \mathrm{EC}$ Treaty, on one hand, and art. 308 EC Treaty, on the other hand. The first two norms set up the material ambit of application of smart sanctions, while the second one, as a closing disposition, fills the gap where no specific provisions of the Treaty confer on the Community institutions express or implied powers to act, but such powers are none the less to be necessary to enable the Community to carry out its functions. Trying to avoid the

\footnotetext{
${ }^{51}$ CFI Joined Cases T-110/03, T-150/03 and T-405/03, Sison v. Council of European Union, [2005] ECR II-1429; EC], C-266/05 P, Sison v. Council of European Union, [2007] ECR I-1233.

${ }^{52}$ In this perspective see DE BURCA (note 19), 38. In particular, the Author recognised that "the CFI demonstrated moderate jurisdictional deference, and the ECJ (and its Advocate General) demonstrated little or no deference".
} 
misleading assessment of the CFI, which used art. 308 EC Treaty as a 'bridge' between the CFSP and the $\mathrm{EC}^{53}$, the ECJ finds a common interest across the different pillars, although aimed at pursuing different purposes: the implementation of actions decided under the CFSP through the imposition of restrictive measures of an economic nature on one hand, and the achievement of the objectives of the Community, in particular the correct working of the common market, on the other. However, the Court did not consider that the objective of the sanctions is clearly that of fighting terrorism and that only incidentally such action can prejudice the competition in the internal market, thus failing to carry out a test of the actual relevance of the measure for the free movement and ultimately used art. 308 EC Treaty as means for the implementation of CFSP goals ${ }^{54}$. Nevertheless, the Court demonstrates to recognise "the coexistence of the Union and the Community as integrated but separate legal orders, and the constitutional architecture of the pillars, as intended by the framers of the Treaties now in force ${ }^{\prime 55}$.

However, this systemic approach also urges the ECJ to cross the formal order of the pillars, leading the train of thought to a substantial reconstruction of the EU domain, in order to pursue a real protection of rights through an effective judicial review. From this point of view, the judicial depillarisation process represents a functional enlargement of the jurisdiction posed by the Treaties, which reveals a gap in the European legal order. Providing solutions rebus sic stantibus, the Court is far from being at the mercy of an activist behaviour, but it is facing the challenge posed by the terrorism issue to the EU's fundamental rights and general principles ${ }^{56}$.

\section{G. Further considerations on the administrative protection of rights}

\footnotetext{
${ }^{53}$ Opinion of Advocate General Poiares Maduro, in the case Yassin Abdullah Kadi v. Council of the European Union and Commission of the European Communities, 16 January 2008, para. 15. In the literature see TRIDIMAS and GUTIERREZ-Fons (note 22), 669-670; HALBERSTAM and STEIN (note 13), 37-39.

${ }^{54}$ See TRIDIMAS and GUTIERREZ-Fons (note 22), 674-678. Moreover, according to HALBERSTAM and STEIN (note 13), 39, the ECJ's decision "was an exercise of statemanship", aimed at "preserv[ing] some limits on Article 308 EC", whilst defining a specific competence of the EC's market, emancipating it from the "effective assistance" to the CFSP.

${ }^{55}$ ECJ Joined cases C-402/05 P e C-415/05 P, para. 202. In this perspective, see TRIDIMAS and GUTIERREZ-Fons (note 22), 679, who realise that the discussion about the competence will be overcome by the entry into force of the Lisbon Treaty, because at art. 215 (2) it recognises the Council power to adopt restrictive measures against individuals, groups and non-state group on the basis of CFSP decisions.

${ }^{56}$ The international terrorism issue is considered "the first truly 'cross-pillar' test of the Union's role as a security actor" by Monica den Boer and Jörg Monar, Keynote Article: 11 September and the Challenge of Global Terrorism to the EU as a Security Actor, 40 JouRnAL OF COMMON MARKET STUdIES 11 (2002). See also J. Monar, Anti-terrorism and policy: the case of the European Union, in GLOBAL ANTI-TERRORISM LAW AND POLICY 425, 449-452 (V.V. Ramraj, M. Hor and K. Roach eds., 2005).
} 
The delineated framework demonstrates that it is possible to consider the ECJ statements on blacklists as an achievement, thus raising a new interpretation of counter-terrorism matters. In other words, the ECJ demonstrated to recognise the necessity to provide a constant protection of rights in terrorist situations. In this perspective, the court has overcome the political-question approach to terrorism, which presupposes an emergency situation and involves a structural judicial deference to emergency decisions, coming to a more confident attitude towards the management of such circumstances. In this regard, it is very persuasive in the Kadi case-law the Opinion of Advocate General Poiares Maduro, who reaffirms the "duty of the courts to assess the lawfulness" of security measures, suggesting that such policies cannot "silence the general principles of Community Law and deprive individuals of their fundamental rights" ${ }^{\prime 57}$ and no "veil should be drawn for a while over liberty, as it was customary to cover the statues of the gods ${ }^{58 \prime}$.

In the attempt to guarantee the effectiveness of the adopted measures, emergency regulations reduce the procedural protection of Positionsrecht (namely, rights), limiting the matching profiles of participation and transparency. From this point of view, the recognition that no derogation can be admitted to the fairness of the administrative proceeding allows the restoration of that basic transparency in the decision-making activity. More precisely, identifying the proceduralisation as a guarantee of the protection of rights, the Court seems to replace the traditional approach to terrorism as an emergency situation with a more fact-fitting assessment, that is its threatening nature. Indeed, in the Kadi case, this perspective was clearly upheld by Advocate General Poiares Maduro, who recognised the duty of the ECJ to verify the existence of "high security risks", and not of emergency situations, and then strike a "proper balance" between the nature of such risks and fundamental rights ${ }^{59}$.

So far, although every decision taken is a precautionary measure, it must be based on a previous analysis of the evidence. In counter-terrorism matters, this means the necessity to restore the guarantees of fairness - first of all the right to a hearing - in the decisionmaking process ${ }^{60}$; at the same time, it implies restoring effectiveness to judicial remedies. In fact, the absence of the emergency state reduces the judges' margin of deference, allowing them to conduct a strict reasoning on the legitimacy of restrictive measures, which will be based on the respect of the due procedure. From this perspective, the ECJ

\footnotetext{
${ }^{57}$ PoIARES MADURO (note 53), para. 34. On the contrary, the ECJ does not comment on this issue, but implicitly it dismisses it, holding that the court has the jurisdiction to review "all Community Acts" (see Joined Cases C-402/05 $\mathrm{P}$ e C-415/05 P, para. 326). In the literature, see KUNOY and DAWES (note 19), 101.

${ }^{58}$ PoiARes MAdURo (note 53), para. 35.

${ }^{59}$ Id., para. 35.

${ }^{60}$ In this perspective see Giacinto della Cananea, Return to the due process of law: the European Union and the fight against terrorism, 32 EUROPEAN LAW REVIEW 895 (2007).
} 
case law, above all the Kadi case, restoring the procedural protection of rights proves to be dealing with the real nature of terrorism, as an actual risk and not as a permanent emergency.

From this standpoint, the administrative proceeding becomes the elected centre for the definition of the relationship between authority and liberty, that is between the imposing public power and the citizens' autonomous subjektive Rechtsstellung (subjective legal positions). In fact, whilst the contested regulations are norms, the procedure of blacklisting people and entities suspected to be affiliated to the terror network is administrative in nature $^{61}$. Smart sanctions are administrative decisions based on intelligence or law enforcement activities and are aimed at affecting the listed parties individually. A general rule is the prohibition to accept any transaction related to those frozen capitals.

More specifically, the characteristics and the degree of the citizens' participation in public decisions determine the kind of relation between those terms; in particular, the institutions of participation, and their complementary means of transparency - inasmuch as the nature of such security-related proceedings permits - allows the discretionary power to be limited, in order to pursue the public interest through the correspondence between individual and collective needs. This procedure grants private parties the chance to protect their rights and interests before the adoption of decisions that are aimed at preserving the common good.

To this end, it is important to define the fundamental guarantees of the process that allow the administration to face risks, so as that it can rule in compliance with the principles and procedures of the democratic tradition. In this perspective, the distinction between the administrative sphere and the criminal jurisdiction is preliminary and decisive, in order not to transform the guarantees of protection provided by administrative law in a dangerous stance for the safeguard of civil liberties. The edge is quite slippery, considering that the legislator is able to move the threshold in both the directions, even though he might do it within the (counter)limits of the constitutional model. In this regard, crime prevention through administrative measures is an enlightening hint, since it is a practice intended to limit criminal activities, by affecting individuals.

In this frame, risk regulation represents the key concept for an accurate understanding of the actual administrative management of the terrorism-related risks and it appears to be a quite indispensable instrument to fight the rise of international violence - as the necessity of public control over the financing of terrorism clearly shows - but also a rather hazardous one, inasmuch as it can have the effect of lowering the overall level of protection against

\footnotetext{
${ }^{61}$ In this perspective see Ch Powell, The Legal Authority of the United Nation Security Council, in SECURITY AND HUMAN RIGHTS 157, 162-163, 165 (B.J. Goold and L. Lazarus eds., 2007), who considers the Security Council an international administrative body, and its action an administrative action, as such constrained to the respect of the global administrative law principles and standards of review.
} 
unfair sanctions. Therefore, the analysis conducted in this essay is aimed at advocating for the restoration of fundamental clauses of protection in the administrative counterterrorism policies, but it is far from taking up a precautionary approach to criminal law. More precisely, the proposed administrative approach to security issues does not seek to suit a general method in the management of terrorism-related issues, but it rather tries to figure out the actual strategy against terrorism and to ensure some guarantees of protection even in such administrative policies. In fact, in the context of risk regulation, the effectiveness of the basic remedies against possible abuses by the executive power can be achieved through the restoration of the fairness criterion in the proceedings and the right to an effective judicial review of administrative decisions, as the ECJ stated in Kadi.

From this perspective, the risk management has to find the best way to offset all the interests at stake, in accordance with the rule of law and the general principles that run the discretionary powers. Due reference is to the key principles of proportionality and precaution, the connected action of which allows to avoid abuse in the implementation of security policies. Both principles guide the striking of a fair balance between the common good of security and the individual expectation to protection of rights.

In particular, the proportionality control satisfies the necessity to establish whether a breach of a fundamental right is lawful, asking "a series of integrated questions ${ }^{62 "}$ aimed at grasping when that limitation is necessary and justified on the ground of a superior public interest and it is carried out in a proper manner, which reduces to the minimum the prejudice to the exercise of fundamental rights ${ }^{63}$. In this perspective, proportionality is not a mere element of reasonableness, but it becomes an autonomous declension of the basic principle of rule of law: being not merely an instrument aimed at striking a fair balance between different interests, but also the structured justification of the decisions' foundation, proportionality rises to a specific criterion to measure the legitimacy of acts ${ }^{64}$.

\footnotetext{
62 Jeffrey Jowell, The Two Faces of Proportionality, paper presented at the IALS SEMINAR, PROPORTIONALITY AND THE Standard of Review after Huang 3, 23 November 2007. See also David Dyzenhaus, Deference, Security and Human Rights, in SECURITY AND HUMAN RIGHTS 125, 146-149 (B.J. Goold and L. Lazarus eds., 2007).

${ }^{63}$ There is an extensive EC case-law on the proportionality principle, which has contributed to design its ambit of application (in particular, it has been developed in the following cases: ECJ Case C 8/55, Fédération Charbonnière, [1955] ECR 291; ECJ Joined Cases 5-11, 13-15/62, Società acciaierie San Michele, [1962] ECR 859; ECJ Case C 18/63, Schmitz [1964] ECR 163; ECJ Case C 29/69, Stauder, [1969] ECR 419; ECJ Case C 11/70, Internationale Handelsgesellschaft, [1970] ECR 1125; ECJ Case C 5/73, Balkan-Import-Export, [1973] ECR 1091; ECJ Case C 182/84, Miro, [1985] ECR 3731). However, on the role played by proportionality in the protection of fundamental rights see ECJ Case C-112/00, Schmidberger, [2003] ECR I-5659; ECJ Case C-36/02, Omega, [2004] ECR I-9609; ECJ Case C 438/05, International Transport Workers' Federation, Finnish Seamen's Union c. Viking Line ABP, OÜ Viking Line Eesti, [2007] ECR I-10779; ECJ Case C-341/05, Laval un Partneri Ltd. c. Svenska Byggnadsarbetareförbundet, Svenska Byggnadsarbetareförbundets avdelning 1, Byggettan, Svenska Elektrikerförbundet, [2007] ECR I-11767. As regard the doctrine, see Nicholas EMILIOU, The PRINCIPLE Of PROPORTIONALITY IN EuROPEAN LAW. A Comparative STUDY (1996).

${ }^{64}$ See JOWELL (note 62), 1-3.
} 
On the other side, the precautionary principle stands at the core of risk regulation ${ }^{65}$, but it shall not be considered as a predetermined decision-making rule in lack of information, as it often happens in environmental matters ${ }^{66}$, but as a further ground of the fact-finding stage in the decisional process. That means it may not to be assumed as a fixed, valuefounded, criterion $^{67}$, but as an epistemological instrument, helpful to understand the actuality of the risk and to reflect on the best way to deal with it. Otherwise, the precautionary action rises to a mechanism able to justify every security measure, even when unreasonable ${ }^{68}$.

In this perspective, proportionality and precaution supply the fact-finding with new means of analysis, contributing to the adoption of more reliable and better-pondered decisions. The success of such methodology, derived from the interpretation of counter-terrorism policies as risk regulation policies, is granted by the system of responsibility that it

\footnotetext{
${ }^{65}$ Even on the precautionary principle, there is a broad EC case-law. See ECJ Case C-178/84, European Commission v. Federal Republic of Germany, [1987] ECR 1227; ECJ Case C-157/96, National Farmers Union, [1998] ECR I-2211, and ECJ, Case C-180/96, UK v. European Commission, [1998] ECR I-2211; ECJ Case C-6/99, Association Greenpeace France and oth.., [2000] ECR I-1651. The assumption among the EC general principles goes back to the CFI Case T-74/00, Artegodan and oth. V. European Commission, [2002] ECR II-4945, and the following decision of the same court Case T-392/02, Solvay Pharmaceuticals v. European Council, [2003] ECR II-4555. Indeed, the CFI Case T-13/99, Pzifer Animal Health SA v. European Council, [2002] ECR II-3305, and Case T-70/99, Alpharma Inc. v. European Council, [2002] ECR II-3495 are very meaningful in the development of the application field and the feature of the principle. Furthermore, see CFI Case T-177/02, Malagutti-Vezinhet v. Commission, [2004] ECR II827, and CFI Case T-229/04, Sweden v. European Commission, [2007] ECR II-2437. However, the origins of the application of the precautionary principle went back to ECJ Case C-174/82, Sandoz, [1983] ECR 2445, where some national healthcare measures were declared incompatible with the freedom of circulation of goods, according to art. 30 EC Treaty. That case developed a principle expressed by the same court in the previous Case C-272/80, Frans-nederlandse maatschappij voor biologiche producten, [1981] ECR 3277. Moreover, see Communication from the Commission on the precautionary principle, 2 February 2000, COM (2000)1 final.

${ }^{66}$ In this regard, a good example is provided by principle 15 of the Rio Declaration on Environment and Development, 3-14 June 1992, which states that "in order to protect the environment, the precautionary approach shall be widely applied by States according to their capabilities. Where there are threats of serious or irreversible damage, lack of full scientific certainty shall not be used as a reason for postponing cost-effective measures to prevent environmental degradation."

${ }^{67}$ This is the strong version of the principle, which is considered paralysing and focusing only on certain aspect of the regulatory situation by Cass R. Sunstein, Beyond the Precautionary Principle, 151 UNIVERSITY OF PENNSYLVANIA LAW REVIEW 1003, 1029-1054 (2003).

${ }^{68}$ A due reference is the judgment of the Bundesverfassungericht, 1 BvR 357/05, 15 February 2006, which declared unconstitutional the art. 14 (3) of Luftsicherheitsgesetz (LuftSiG) 11 January 2005, the Act on security of flights, inasmuch as it authorised the army to shoot down an hijacked airplane, should there be a reasonable certainty that that plane would be used as an improper weapon against national targets. The court deemed the right to life of passengers and the crew untouchable, and stopped any national preventive action on the threshold of the Constitutional State, governed by the rule of law. In this perspective, the court allowed precautionary interventions only in those cases in which hijackers were to be on the plane, in accordance with the proportionality principle. For an analysis of the judgment, see Vincenzo Baldini, Stato di prevenzione v/Stato costituzionale di diritto: un nuovo capitolo di una storia infinita, Jus 463(2006).
} 
introduces in the decision-making process. In short, it has the capability to connect the respective charge of the burden of proof to the attribution of the decisional power. In fact, the precautionary principle imposes the liability of the decision on the settling institution, so that the same responsibility of the risk assessment is on those administrations that pronounce on the management of the risk.

On the other hand, conceiving the proportionality principle as a structured justification involves the administrative burden to demonstrate that the restrictions on the fundamental rights are limited to the strictly necessary measures to pursue the public interest $^{69}$. In line with this reasoning, the possibility of individuals to protect their fundamental rights tends to increase in parallel with the restoration of the accountability principle in the administrative action.

In this perspective, the setting up of European security can thwart the drawing of a veil over the rule of law and the principles of democratic States and on this legal framework it can anchor the research of a European model for security of rights.

${ }^{69}$ See JOWELL (note 62), 1-4. 